\title{
A Functional Model for the Cysteinate-Ligated Non-Heme Iron Enzyme Superoxide Reductase (SOR)
}

\author{
Terutaka Kitagawa, Abishek Dey, Priscilla Lugo-Mas, Jason B. Benedict, Werner Kaminsky, \\ Edward Solomon ${ }^{*}$, and Julie A. Kovacs \\ Department of Chemistry, University of Washington, Seattle, WA 98195; Department of Chemistry, \\ Stanford University, Palo Alto, CA 94304
}

Superoxide reductases (SORs) are cysteinate-ligated non-hemeiron enzymes ${ }^{1}$ that reduce superoxide $\left(\mathrm{O}_{2}^{-}\right)$to $\mathrm{H}_{2} \mathrm{O}_{2}$ in anaerobicmicrobes. ${ }^{2}$ The cysteinate of SOR is trans to the $\mathrm{O}_{2}{ }^{-}$ binding site, and is proposed to play an important role in promoting the catalytic reaction. Herein, we report a rare example of a functional metalloenzyme active site model, that reduces $\mathrm{O}_{2}{ }^{-}$via atrans thiolate-ligated $\mathrm{Fe}(\mathrm{III})-$ peroxo intermediate. The trans thiolate is shown to lower the redox potential, change the spin-state, and dramatically weaken the $\mathrm{Fe}-\mathrm{O}$ bond, favoring $\mathrm{O}_{2}^{-}$reduction and $\mathrm{H}_{2} \mathrm{O}_{2}$ release.

Superoxide is a toxic byproduct of dioxygen chemistry that has been linked to a number of disease states. ${ }^{3}$ The proposed SOR mechanism involves the oxidative addition of $\mathrm{O}_{2}{ }^{-}$to the open site of the square pyramidal $\mathrm{Fe}^{\mathrm{II}} \mathrm{N}_{4}$ His $\mathrm{S}^{\mathrm{Cys}}$ active site ${ }^{2 \mathrm{c}}$ to afford a trans $\mathrm{S}^{\mathrm{cys}}$-ligated $\mathrm{Fe}^{\text {III }}$-peroxo intermediate. ${ }^{2 \mathrm{~d}, \mathrm{e}}$ This intermediate displays an intense S-to-Fe(III) charge transfer band at $\sim 600(\sim 3500) \mathrm{nm}$, but has yet to be characterized by vibrational spectroscopy. Iron-peroxo species are extremely difficult to characterize since they are thermally unstable, and photolabile. Vibrational data have been reported for mutant SOR (E47A) peroxos generated via the addition of $\mathrm{H}_{2} \mathrm{O}_{2} \cdot{ }^{2} \mathrm{~b}, \mathrm{f}, \mathrm{g}$ Whether these are identical to the catalytic SOR intermediate remains to be determined. Although a few well-characterized synthetic nitrogenligated iron-peroxos have been reported, ${ }^{4 a, c}$ there is a paucity of thiolate-ligated analogues. $4 \mathrm{~b}$ Since a thiolate is likely to influence the correlation between peroxide binding mode, vibrational parameters, and spin-state, synthetic thiolate-ligated peroxos are needed to provide benchmark parameters. Prior to the work reported herein, cis thiolate-ligated $\left[\mathrm{Fe}^{\mathrm{III}}\left(\mathrm{S}^{\mathrm{Me} 2} \mathrm{~N}_{4}(\text { tren })\right)(\mathrm{OOH})\right]^{+}(\mathbf{1}),{ }^{4 \mathrm{~b}}$ was the only reported example of a synthetic thiolateligated $\mathrm{Fe}^{\mathrm{III}}$-peroxo.

In situ deprotection and deprotonation of the new macrocyclic ligand cyclam-PrS-Ac.4HCl, afforded $\left[\mathrm{Fe}^{\mathrm{II}}(\right.$ cyclam- $\left.\mathrm{PrS})\right]\left(\mathrm{BPh}_{4}\right)(2)$ upon the addition of $\mathrm{FeCl}_{2}$ and $\mathrm{NaBPh}_{4}$. Single crystals were grown from pentane/THF at $-30^{\circ} \mathrm{C}$. As shown in the ORTEP (Figure 1), the $\mathrm{Fe}^{2+}$ ion of $\mathbf{2}$ is ligated by three secondary amines, one tertiary amine, and a tethered apical thiolate in a square pyramidal geometry $(\tau=0.13)^{5}$ resembling that of SOR. A related tertiary amine cyclam complex $\left[\mathrm{Fe}^{\mathrm{II}}\left(\mathrm{Me}_{3} \text {-cyclam-EtS }\right)\right]^{+}(3)$ was recently reported ${ }^{6}$ that reacts with $\mathrm{H}_{2} \mathrm{O}_{2}$ to afford an $\mathrm{Fe}(\mathrm{IV})=\mathrm{O} .{ }^{7}$ Like the SOR active site, 2 is high spin $\left(\mathrm{S}=2 ; \mu_{\mathrm{eff}}=5.03 \mathrm{BM}(\mathrm{MeCN}) ; 4.91 \mathrm{BM}\right.$ (solid)). The Fe-S bond length in 2 (2.286(1) $⿱$ A) falls in the usual range for synthetic Fe(II)thiolates, ${ }^{6,8}$ but is slightly shorter than that of $\mathrm{SOR}(\mathrm{Fe}-\mathrm{S}=2.4 \AA$ ), the cysteinate sulfur of which is $\mathrm{H}$-bonded to the protein backbone. ${ }^{2 \mathrm{a}, \mathrm{c}}$

Thiolate-ligated 2 reacts rapidly with $\mathrm{O}_{2}{ }^{-\bullet}\left(18\right.$-crown-6- $\mathrm{K}^{+}$salt $)$in $\mathrm{CH}_{2} \mathrm{Cl}_{2}$ at $-78^{\circ} \mathrm{C}$ to afford a metastable burgundy intermediate, as soon as a proton donor ( $\mathrm{MeOH} ; 82$ equiv) is added. 
This intermediate is high-spin $(\mathrm{g}=7.72,5.40,4.15)$, and displays an absorption band at $\lambda_{\max }=$ 530(1350) $\mathrm{nm}$. Resonance Raman shows $v_{\mathrm{O}-\mathrm{O}}, v_{\mathrm{Fe}-\mathrm{O}}$, and $v_{\mathrm{Fe}-\mathrm{S}}$ stretches at $891 \mathrm{~cm}^{-1}(\mathrm{Fermi}$ doublet), $419 \mathrm{~cm}^{-1}$, and $352 \mathrm{~cm}^{-1}$, respectively (Figure 2). $\mathrm{K}^{18} \mathrm{O}_{2}$ (50\% enriched; ICON) causes the $v_{\mathrm{O}-\mathrm{O}}$ and $v_{\mathrm{Fe}-\mathrm{O}}$ to shift to $856 \mathrm{~cm}^{-1}$ and $400 \mathrm{~cm}^{-1}$, respectively, and addition of $\mathrm{D}^{+}(\mathrm{ie}, \mathrm{MeOD})$ causes the Fermi doublet to collapse. These data are consistent with the formation of an $\mathrm{Fe}$-hydroperoxo species, $\left[\mathrm{Fe}^{\mathrm{III}}(\text { cyclam- } \mathrm{PrS})(\mathrm{OOH})\right]^{+}(4)$, via the protondependent oxidative addition of superoxide to 2 . No reaction occurs in the absence of a proton donor, and $\mathrm{O}_{2}{ }^{-}$does not convert to $\mathrm{H}_{2} \mathrm{O}_{2}$ in the absence of $\mathbf{2}$, under the conditions examined $\left(-78^{\circ} \mathrm{C}, 82\right.$ equiv $\left.\mathrm{MeOH}\right)$. Intermediate 4 represents the first example of a synthetic trans thiolate-ligated $\mathrm{Fe}^{\mathrm{III}}$-peroxo SOR intermediate analogue, the characterization of which provides important benchmark parameters.

The $v_{\mathrm{Fe}-\mathrm{O}}$ stretch of $\mathbf{4}$ is significantly lower than all other reported synthetic iron peroxides (range: $\left.450-639 \mathrm{~cm}^{-1}\right),{ }^{4 a}$ but compares well with that of the only reported SOR peroxo (438 $\left.\mathrm{cm}^{-1}\right){ }^{2 \mathrm{a}, \mathrm{e}}$ The $v_{\mathrm{O}-\mathrm{O}}$ stretch $\left(891 \mathrm{~cm}^{-1}\right)$ is unusually high (reported range: $820-860 \mathrm{~cm}^{-1}$ ).

$4 \mathrm{a}$ The DFT optimized structure of $\mathbf{4}$ minimizes with Fe-S and Fe-O distances of $2.36 \AA$ and $1.95 \AA$, respectively, and a protonated peroxo O-O distance of $1.44 \AA$. This Fe-O(peroxo) distance is significantly longer than the few reported Fe- $(\eta 1-\mathrm{OOH})$ structures $(1.76-1.86 \AA)$ $4 \mathrm{a}$ reflecting the trans influence of the thiolate sulfur. The calculated $v_{\mathrm{Fe}-\mathrm{S}}\left(345 \mathrm{~cm}^{-1}\right)$, $v_{\mathrm{Fe}-\mathrm{O}}\left(400 \mathrm{~cm}^{-1}\right)$ and $v_{\mathrm{O}-\mathrm{O}}\left(933 \mathrm{~cm}^{-1}\right)$ stretches are in reasonable agreement with the experimental data. When the thiolate is replaced with an amine, or alkoxide, trans to the peroxo, 9 then the calculated $v_{\mathrm{Fe}-\mathrm{O}}\left(495 \mathrm{~cm}^{-1}\right.$ and $420 \mathrm{~cm}^{-1}$, respectively) is considerably higher. These vibrational data, along with the calculated force constant $\left(k_{\mathrm{Fe}-\mathrm{O}}=1.20 \mathrm{mdynes} / \mathrm{cm}^{2}\right.$ for 4 vs reported range $=2.2-2.1$ mdynes $\left./ \mathrm{cm}^{2}\right),{ }^{4 \mathrm{a}}$ indicate that the $\mathrm{Fe}-\mathrm{O}$ (peroxide) bond is significantly weakened upon the introduction of a trans thiolate into the coordination sphere.

Addition of HOAc to metastable 4 at $-78{ }^{\circ} \mathrm{C}$ releases $\mathrm{H}_{2} \mathrm{O}_{2}$ (as detected using an amplex red assay), and cleanly affords a new aqua blue species $\lambda_{\max }=604(1350) \mathrm{nm}$ (Figure 3 ). When this reaction is monitored by EPR, the high-spin signal associated with $\mathbf{4}$ is replaced with a new low-spin signal at $\mathrm{g}=2.37,2.30,1.89$. The $v_{\mathrm{O}-\mathrm{O}}$ and $v_{\mathrm{Fe}-\mathrm{O}}$ stretches disappear in the rRaman spectrum, and new stretches are observed at 339,409 , and $421 \mathrm{~cm}^{-1}$. Although this aqua blue species proved too unstable to isolate, it was unambiguously identified by ESI-mass spectrometry as acetate-bound $\left[\mathrm{Fe}^{\mathrm{III}}(\text { cyclam-PrS })(\mathrm{OAc})\right]^{+}(\mathbf{5})$, a model for Glu-bound SOR.

Addition of a sacrificial reductant $\left(\mathrm{Cp}_{2} \mathrm{Co}\right)$ to $\mathbf{5}$ at low temperatures $\left(-78^{\circ} \mathrm{C}\right)$ regenerates $\mathbf{2}$, which then reacts with a second equiv of $\mathrm{O}_{2}{ }^{-\bullet}$ to re-afford peroxo 4 . Addition of a second equiv of HOAc releases $\mathrm{H}_{2} \mathrm{O}_{2}$ (Figure 4), thereby mimicking the proposed SOR catalytic cycle involving glutamic acid, ${ }^{2}, \mathrm{e}, 1$ and demonstrating that reduction of $\mathrm{O}_{2}^{-\bullet}$ by 2 is catalytic. Thus far, five turnovers have been achieved.

The thiolate ligand and its trans positioning relative to the substrate appear to contribute significantly to the function of our biomimetic catalyst. First, the pendent thiolate arm of $\mathbf{2}$ causes the redox potential to shift anodically by $+480 \mathrm{mV}$ relative to $\left[\mathrm{Fe}^{\mathrm{II}}(\right.$ cyclam $\left.)(\mathrm{MeCN})_{2}\right]$ (from $+700 \mathrm{mV}$ to $+220 \mathrm{mV}$ vs SCE), making it better suited to promote superoxide reduction. Second, the trans thiolate changes the spin-state from $S=1 / 2^{4 b}$ to $S=5 / 2$ : the majority of nitrogen-ligated $\mathrm{Fe}(\mathrm{III})-\mathrm{OOH}$ 's are $\mathrm{S}=1 / 2,{ }^{4 \mathrm{a}}$ as is cis-thiolate ligated $1{ }^{4 \mathrm{~b}}$ Third, the thiolate dramatically shifts the $v_{\mathrm{Fe}-\mathrm{O}}$ stretch and decreases the $k_{\mathrm{Fe}-\mathrm{O}}$ force constant well-below all other reported iron peroxides. ${ }^{4 \mathrm{a}}$ Peroxo 4 partially converts to methoxide-bound $\left[\mathrm{Fe}^{\mathrm{III}}\right.$ (cyclam-PrS) $(\mathrm{OMe})]^{+}\left(6 ; \mathrm{g}=2.34,2.26,1.95 ; v_{\mathrm{Fe}-\mathrm{S}}=357 \mathrm{~cm}^{-1}\right)$ within minutes at $-78{ }^{\circ} \mathrm{C}$, whereas cisligated peroxo 1 takes hours $\left(\mathrm{t}_{1 / 2}=63.9 \mathrm{hrs}\right)$ to convert to $\left[\mathrm{Fe}^{\mathrm{III}}\left(\mathrm{S}^{\mathrm{Me} 2} \mathrm{~N}_{4}(\text { tren })\right)(\mathrm{OMe})\right]^{+}$under the same conditions. Methoxide-bound $\mathbf{6}$ was identified via its independent synthesis involving $\mathrm{Cp}_{2} \mathrm{Fe}^{+}$oxidation of 2 in $\mathrm{MeOH}$, in the presence of ${ }^{i} \operatorname{Pr}_{2} \mathrm{EtN}$. 
In conclusion, the data described herein indicates that like the enzyme, SOR intermediateanalogue $\mathbf{4}$ is better suited to promote $\mathrm{Fe}-\mathrm{O}$, as opposed to $\mathrm{O}-\mathrm{O}$, bond cleavage. This is in contrast to $\mathrm{P} 450$ and its analogue 3 . Kinetics studies, and studies aimed at determining the $\mathrm{pK}_{\mathrm{a}}$ of the proximal and distal peroxo oxygens of $\mathbf{4}$ are currently underway.

\section{Supplementary Material}

Refer to Web version on PubMed Central for supplementary material.

\section{Acknowledgements}

This research was supported by NIHGM45881 (J.A.K.), GM40392 (E.I.S.), and F31 GM73583 (P. L.- M.).

\section{References}

1. Kovacs JA. Chem Rev 2004;104:825-848. [PubMed: 14871143]

2. (a) Kurtz DM Jr. Acc Chem Res 2004;37:902-908. [PubMed: 15612680] (b) Mathé C, Nivire V, Houée-Levin C, Mattioli TA. Biophys Chem 2006;119:38-48. [PubMed: 16084640] (c) Yeh AP, Hu Y, Jenney FE Jr, Adams MWW, Rees DC. Biochemistry 2000;39:2499-2508. [PubMed: 10704199] (d) Emerson JP, Coulter ED, Cabelli DE, Phillips RS, Kurtz DM Jr. Biochemistry 2002;41:4348-4357. [PubMed: 11914081] (e) Niviere V, Asso M, Weill CO, Lombard M, et al. Biochemistry 2004;43:808818. [PubMed: 14730986] (f) Mathe C, Mattioli TA, Horner O, Lombard M, Latour J-M, Fontecave M, Niviere V. J Am Chem Soc 2002;124:4966-4967. [PubMed: 11982354] (g) Horner O, Oddou JL, Niviere V, Fontecave M, Halfen JA, Latour J-M, et al. Biochemistry 2004;43:8815-8825. [PubMed: 15236590] (h) Mathé C, Nivière V, Mattioli TA. J Am Chem Soc 2005;127:16436-16441. [PubMed: 16305229] (i) Clay MD, Jenney FE Jr, Hagedoorn PL, George GN, Adams MWW, Johnson MK. J Am Chem Soc 2002;124:788-805. [PubMed: 11817955] (j) Jovanovic T, Krebs C, Moura I, Moura JJG, Radolf JD, Huynh BH, Rusnak F, et al. J Biol Chem 2000;275:28439-28448. [PubMed: 10874033]

3. (a) Gogun Y, Sakurada S, Kimura Y, Nagumo M. J Clin Biochem Nutr 1990;8:85-92. (b) Kocaturk PA, Akbostanci MC, Tan F, Kavas GO. Pathophysiology 2000;7:63-67. [PubMed: 10825687] (c) Ihara Y, Chuda M, Kuroda S, Hayabara T. J Neurol Sci 1999;170:90-95. [PubMed: 10561523] (d) De Leo ME, Borrello S, Passantino M, Palazzotti B, Galeotti T, Masullo C, et al. Neurosci Lett 1998;250:173-176. [PubMed: 9708860]

4. (a) Roelfes G, Ho RYN, Rohde J-U, Feringa BL, Munck E, Que L Jr, et al. Inorg Chem 2003;42:2639_ 2653. [PubMed: 12691572] (b) Shearer J, Scarrow RC, Kovacs JA. J Am Chem Soc 2002;124:11709_ 11717. [PubMed: 12296737] (c) Bolland V, Banse F, Mattioli TA, Blondin G, Girerd JJ, et al. Inorg Chem 2003;42:2470-2477. [PubMed: 12665386]

5. Addision AW, Rao TN, Reedijk J. J Chem Soc Dalton Trans 1984:1349.

6. Fiedler AT, Halfen JA, Brunold TC. J Am Chem Soc 2005;127:1675-1689. [PubMed: 15701002]

7. Bukowski MR, Koehntop KD, Stubna A, Bominaar EL, Halfen JA, Munck E, Nam W, Que L Jr. Science 2005;310:1000-1002. [PubMed: 16254150]

8. (a) Shearer J, Nehring J, Kaminsky W, Kovacs JA. Irong Chem 2001;40:5483-5484. (b) Noveron JC, Olmstead MM, Mascharak PK. J Am Chem 2001;123:3247-3259.

9. Lehnert N, Ho RYN, Que L Jr, Solomon EI. J Am Chem Soc 2001;123:12802-12816. [PubMed: 11749538] 


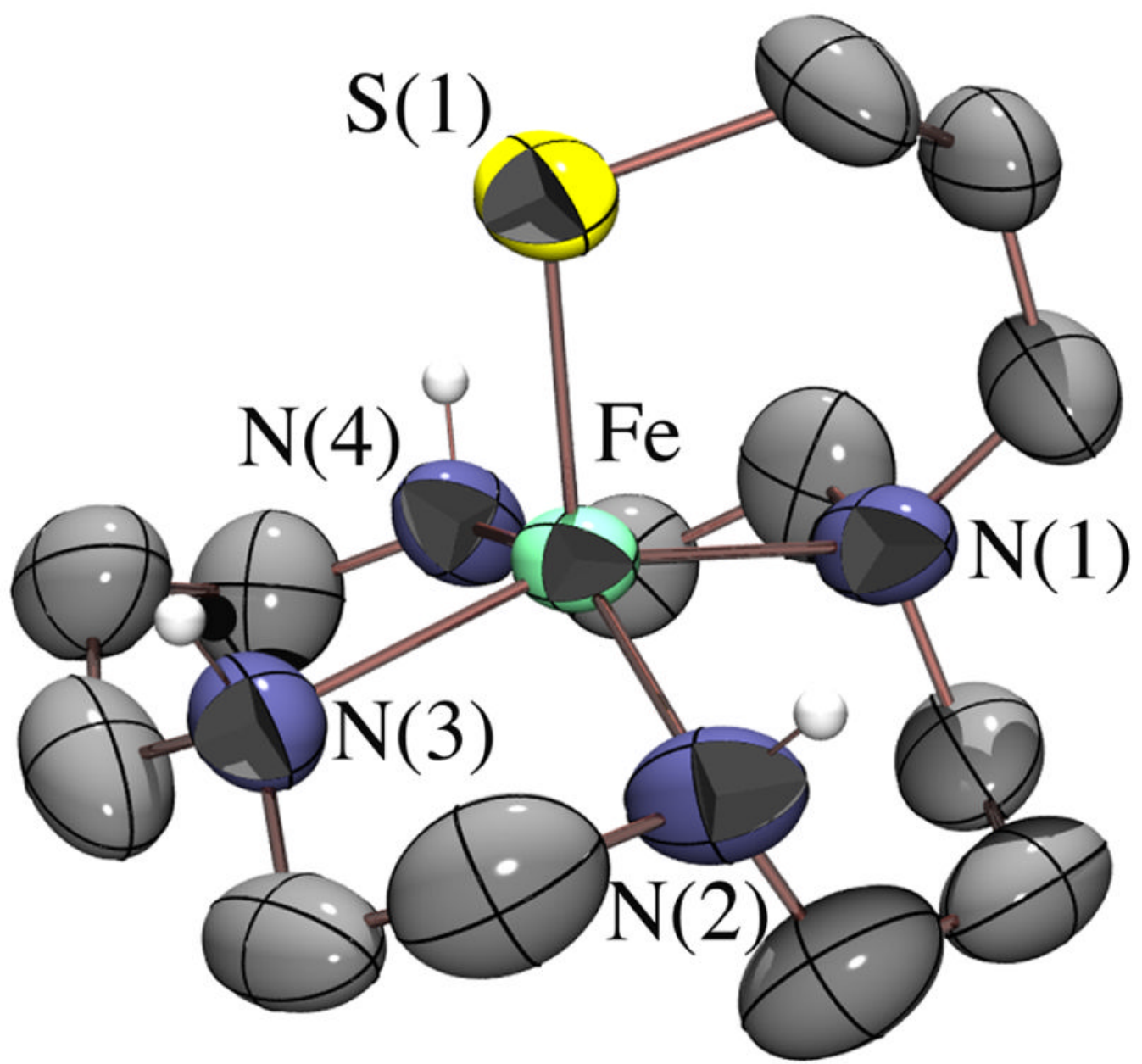

Figure 1.

ORTEP of [Fe ${ }^{\mathrm{II}}($ cyclam-PrS $\left.)\right]^{+}$(2). Selected bond lengths $(\AA)$ : $\mathrm{Fe}-\mathrm{S}(1), 2.286(1) ; \mathrm{Fe}-\mathrm{N}(1)$, 2.181(4); $\mathrm{Fe}-\mathrm{N}(2,3,4)_{\mathrm{avg}}, 2.16(2)$. 

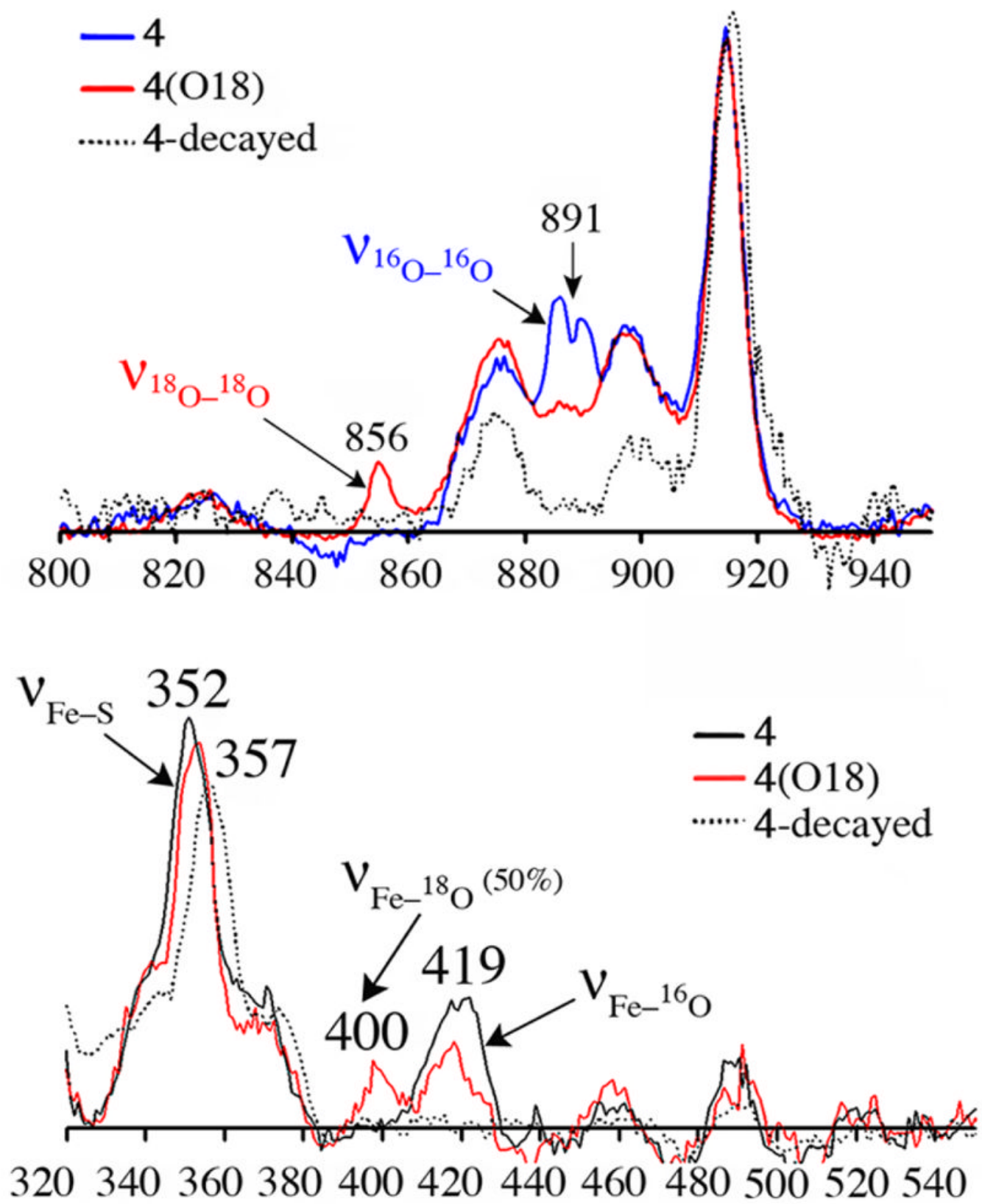

Figure 2.

rRaman spectra of 4 generated from ${ }^{16} \mathrm{O}_{2}{ }^{-}$(blue), ${ }^{18} \mathrm{O}_{2}{ }^{-}$(red), and "decayed" product (dashed black) (571 nm excitation @ $183 \mathrm{~K}$ in THF/MeOH (upper panel); @ $77 \mathrm{~K}_{\text {in }} \mathrm{CH}_{2} \mathrm{Cl}_{2} / \mathrm{THF} /$ $\mathrm{MeOH}$ (lower panel). 


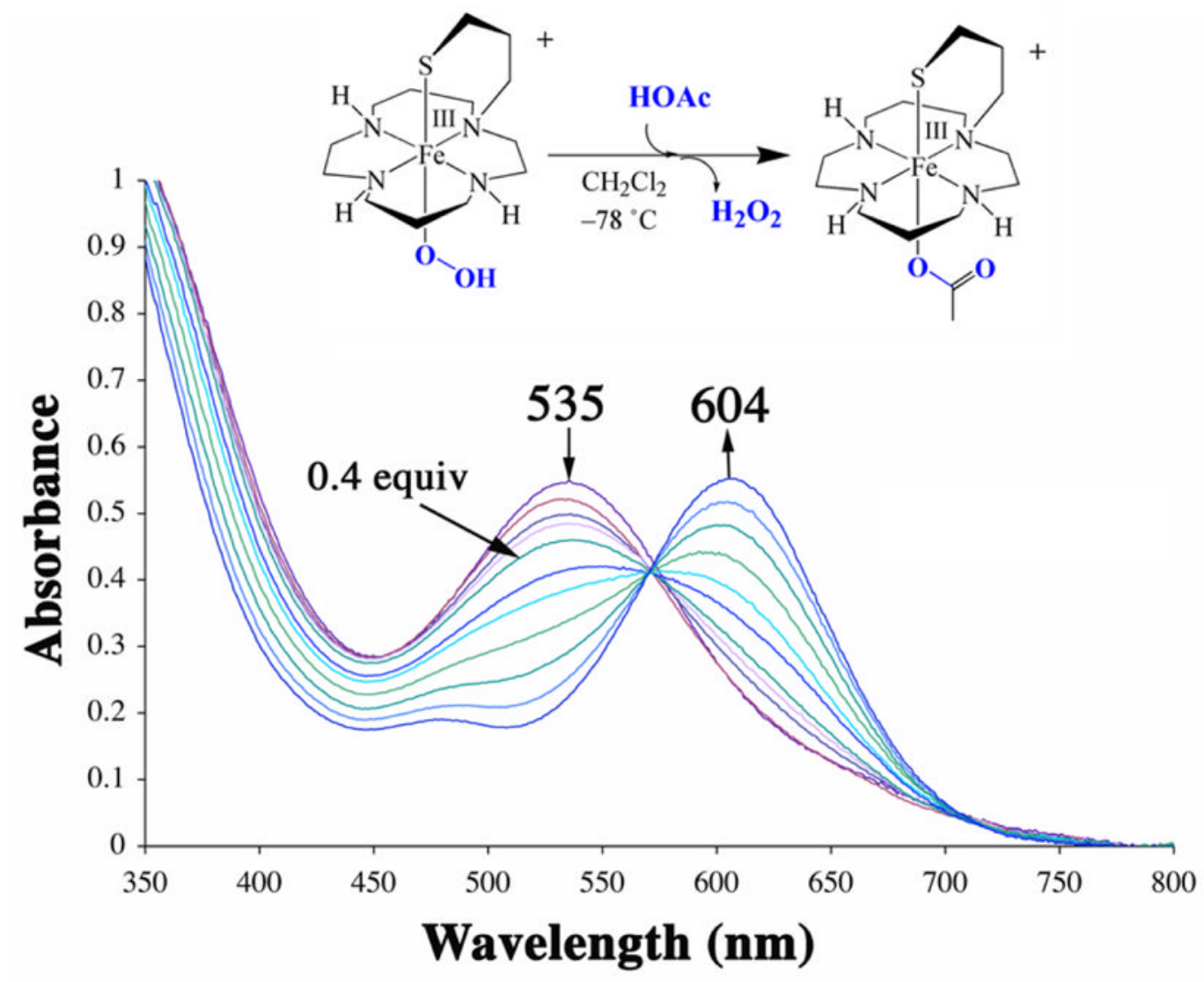

Figure 3.

Conversion of peroxo-bound $4\left(0.5 \mathrm{mM}\right.$ in $\left.\mathrm{CH}_{2} \mathrm{Cl}_{2}\right)$ to acetate-bound [ $\mathrm{Fe}^{\mathrm{III}}($ cyclam-PrS $)$ $(\mathrm{OAc})]^{+}(\mathbf{5})$ via the addition of $\mathrm{HOAc}(0.1$ equivaliquots every two minutes $)$ at $-78{ }^{\circ} \mathrm{C}$. 


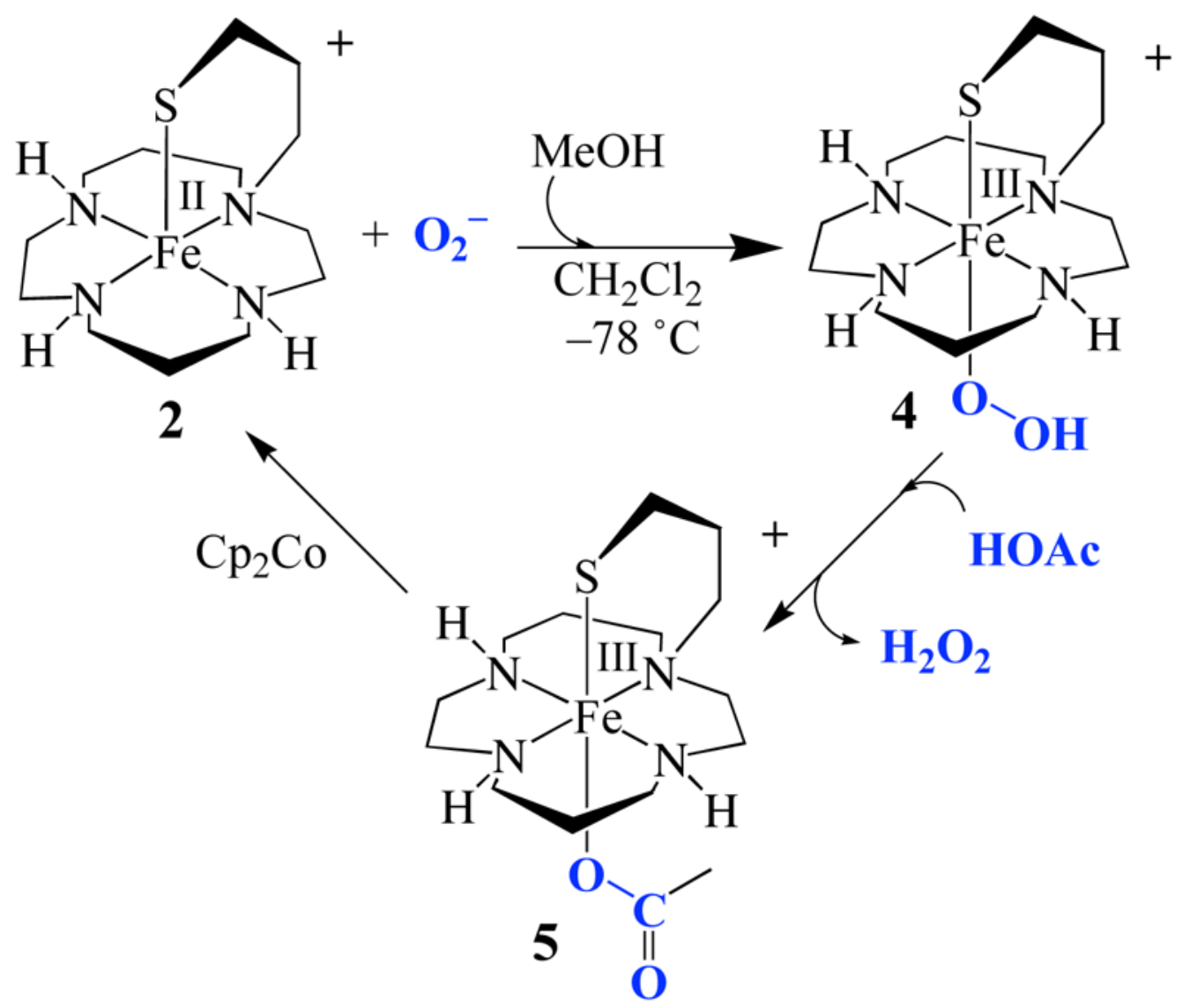

Figure 4.

The catalytic cycle involving $\left[\mathrm{Fe}^{\mathrm{II}}(\text { cyclam-PrS })\right]^{+}(\mathbf{2})$ induced superoxide $\left(\mathrm{O}_{2}^{-}\right)$reduction 